\title{
Synergistic effects of high fat feeding and apolipoprotein E deletion on enterocytic amyloid-beta abundance
} Susan Galloway ${ }^{1}$, Menuka MS Pallebage-Gamarallage ${ }^{1}$, Ryusuke Takechi ${ }^{1}$, Le Jian ${ }^{1}$, Russell D Johnsen ${ }^{2,3}$, Satvinder S Dhaliwal ${ }^{1}$ and John CL Mamo*1

Address: ${ }^{1}$ School of Public Health and Australian Technology Network (ATN), Centre for Metabolic Fitness, Curtin University of Technology, Perth, Western Australia, ${ }^{2}$ Australian Neuromuscular Research Institute, QEII Medical Centre, Perth, Western Australia and ${ }^{3}$ Centre for Neuromuscular and Neurological Disorders, University of Western Australia

Email: Susan Galloway - susan.galloway@postgrad.curtin.edu.au; Menuka MS Pallebage-Gamarallage -mmenuka@hotmail.com; Ryusuke Takechi - ryusuke.takechi@postgrad.curtin.edu.au; Le Jian - L.Jian@Curtin.edu.au; Russell D Johnsen - rjohnsen@cyllene.uwa.edu.au; Satvinder S Dhaliwal - S.Dhaliwal@Curtin.edu.au; John CL Mamo* - J.Mamo@Curtin.edu.au

* Corresponding author

\section{Published: 22 April 2008}

Lipids in Health and Disease 2008, 7:15 doi:10.1186/1476-51IX-7-15

This article is available from: http://www.lipidworld.com/content/7///15

(c) 2008 Galloway et al; licensee BioMed Central Ltd.

This is an Open Access article distributed under the terms of the Creative Commons Attribution License (http://creativecommons.org/licenses/by/2.0), which permits unrestricted use, distribution, and reproduction in any medium, provided the original work is properly cited.
Received: 29 January 2008

Accepted: 22 April 2008

\begin{abstract}
Background: Amyloid- $\beta(A \beta)$, a key protein found in amyloid plaques of subjects with Alzheimer's disease is expressed in the absorptive epithelial cells of the small intestine. Ingestion of saturated fat significantly enhances enterocytic $A \beta$ abundance whereas fasting abolishes expression. Apolipoprotein (apo) $E$ has been shown to directly modulate $A \beta$ biogenesis in liver and neuronal cells but it's effect in enterocytes is not known. In addition, apo $E$ modulates villi length, which may indirectly modulate $A \beta$ as a consequence of differences in lipid absorption. This study compared $A \beta$ abundance and villi length in wild-type (WT) and apo $E$ knockout (KO) mice maintained on either a low-fat or high-fat diet. Wild-type C57BL/6) and apo E KO mice were randomised for sixmonths to a diet containing either $4 \%(\mathrm{w} / \mathrm{w})$ unsaturated fats, or chow comprising $16 \%$ saturated fats and $1 \%$ cholesterol. Quantitative immunohistochemistry was used to assess $A \beta$ abundance in small intestinal enterocytes. Apo E KO mice given the low-fat diet had similar enterocytic A $\beta$ abundance compared to WT controls.

Results: The saturated fat diet substantially increased enterocytic $A \beta$ in WT and in apo $E$ KO mice, however the effect was greater in the latter. Villi height was significantly greater in apo E KO mice than for WT controls when given the low-fat diet. However, WT mice had comparable villi length to apo E KO when fed the saturated fat and cholesterol enriched diet. There was no effect of the high-fat diet on villi length in apo E KO mice.
\end{abstract}

Conclusion: The findings of this study are consistent with the notion that lipid substrate availability modulates enterocytic $A \beta$. Apo $E$ may influence enterocytic lipid availability by modulating absorptive capacity.

\section{Background}

Net concentration of cerebral $\mathrm{A} \beta$ is determined by the presence of apolipoprotein (apo) E with a dose dependent gene effect of apo E -/- < apo E -/+ < apo E +/+ on hippocampal senile plaques $[1,2]$. Animals and cell culture studies show that apo E regulates the production, transport, 
clearance and solubility of $A \beta$ [1-8]. Apolipoprotein $E$ may modulate cerebral $A \beta$ homeostasis by regulating cerebral $\mathrm{A} \beta$ efflux via the low-density-lipoprotein-receptorrelated protein (LRP), relative to the influx of $A \beta$ via transporters such as the receptor for advanced-glycation-endproducts (RAGE) [9]. In addition, apo E can also directly influence $A \beta$ biogenesis via regulation of $\alpha$ - and $\beta$-secretases activity [10], or indirectly, by influencing the intracellular pool of regulating lipids [11].

Apolipoprotein E critically regulates cholesterol metabolism and lipid homeostasis. The apo E protein is the primary receptor ligand for dietary-derived lipoproteins synthesized by the small intestine (chylomicrons) and triglyceride-rich lipoproteins (very-low-density lipoproteins (VLDL)), synthesized from liver [12]. Several lines of evidence support a link between aberrations in lipid metabolism and AD risk [7,11,13]. Epidemiological and clinical studies suggest that a high intake of saturated fat and/or cholesterol accelerate onset and progression of $\mathrm{AD}$, whereas some polyunsaturated fatty acids may be protective [13-17]. Moreover, strong evidence of a causal relationship between dietary fats and $\mathrm{AD}$ comes from feeding studies in mice or rabbits. Animals given saturated-fat diets show significant immuno-detectable cerebral $A \beta$ burden [18-20], although the mechanisms by which this occurs are presently unclear.

Our laboratory recently reported that absorptive epithelial cells of the small intestine secrete $A \beta$ associated with dietary-derived lipoproteins (chylomicrons) [21]. A diet enriched in saturated fats and cholesterol was found to markedly increase enterocytic $A \beta$, whereas fasting completely abolished $A \beta$ production. Chronic ingestion of saturated-fat may lead to sustained elevations in blood of lipoprotein-bound $A \beta$, because of overproduction and thereafter, reduced clearance from blood. Moreover, recent studies suggest that exaggerated exposure to circulating $A \beta$ may compromise blood-brain-barrier integrity and exacerbate cerebral amyloidosis [22]. In normal subjects, approximately $60 \%$ of lipoprotein-bound plasma $\mathrm{A} \beta$ is associated with the triglyceride-rich-lipoproteins
(TRL's) and in subjects with $\mathrm{AD}$, post-absorptive accumulation of chylomicrons has been identified [23].

Apolipoprotein E is pivotal for the interaction of TRL with high affinity clearance pathways [12] including the lowdensity-lipoprotein-receptor (LDL-r) and LRP and will therefore significantly influence plasma lipoprotein- $\mathrm{A} \beta$ concentration and kinetics. However, apo E may also influence plasma $A \beta$ homeostasis by modulating synthesis and secretion of the lipoprotein- $\mathrm{A} \beta$ complex from either the intestine and/or liver. To explore this concept further, in this study we compared enterocytic $A \beta$ homeostasis in wild-type mice versus animals devoid of apo $\mathrm{E}$ (apo E knockouts). Mice were given either a low-fat, or high saturated-fat diet to explore synergistic effects. We find that apo E modulates intestinal morphology in a manner which may influence lipid absorptive capacity and has a synergistic effect with dietary fats on enterocytic $\mathrm{A} \beta$ homeostasis.

\section{Results \\ High-fat feeding induced hypercholesterolemia in apo $E$ KO mice}

Apo E KO mice given low-fat chow had significantly elevated plasma cholesterol compared to WT mice on the low-fat diet (table 1), however plasma triglycerides were not significantly affected because of the gene deletion. In WT mice the high saturated fat diet had no significant affect on plasma cholesterol or triglycerides (table 1). However, in apo E KO mice hypercholesterolemia was substantially exacerbated and some two-fold greater than the apo E KO mice given low-fat chow. All groups of mice gained weight during the intervention and there was no significant difference between treatment groups (data not shown).

\section{Immunolocalisation of $A \beta$ in the small intestine of apolipoprotein E KO mice: synergistic effects of high fat feeding}

For all groups of mice, $A \beta$ immunostaining was demonstrated within the perinuclear region of absorptive columnar epithelial cells of the small intestine mucosa (insert, figure 1). With low-fat feeding, WT and apo E KO mice

Table I: Plasma lipids in wild-type and apolipoprotein E knockout mice fed low and high fat diets

\begin{tabular}{cccc}
\hline Diet & Gene & Cholesterol $(\mathrm{mM})$ mean \pm S.E.M & Triglyceride $(\mathrm{mM})$ mean \pm S.E.M \\
\hline LF & WT & $2.1 \pm 0.05$ & $0.69 \pm 0.19$ \\
LF & Apo E KO & $* 6.95 \pm 1.97$ & $0.68 \pm 0.09$ \\
HF & WT & $2.2 \pm 0.46$ & $0.42 \pm 0.12$ \\
HF & Apo E KO & $* 14.3 \pm 0.01$ & $0.38 \pm 0.12$ \\
\hline
\end{tabular}

$* p<0.05$

S.E.M = standard error of the mean

Table shows plasma cholesterol and triglyceride concentrations (mean \pm SEM, $n=6$ mice per group) in C57BL/6J WT mice and apo E KO mice maintained on either LF or HF diet for six-months. Apo E KO mice had significantly elevated levels of plasma cholesterol compared to WT controls under both feeding regimens $(P<0.05)$. High-fat feeding further exacerbated the elevation of cholesterol in apo $E$ KO mice compared to HF-WT $(P<$ $0.001)$ and LF-APOE KO mice $(P<0.05)$. Plasma triglyceride was not significantly different between groups. 

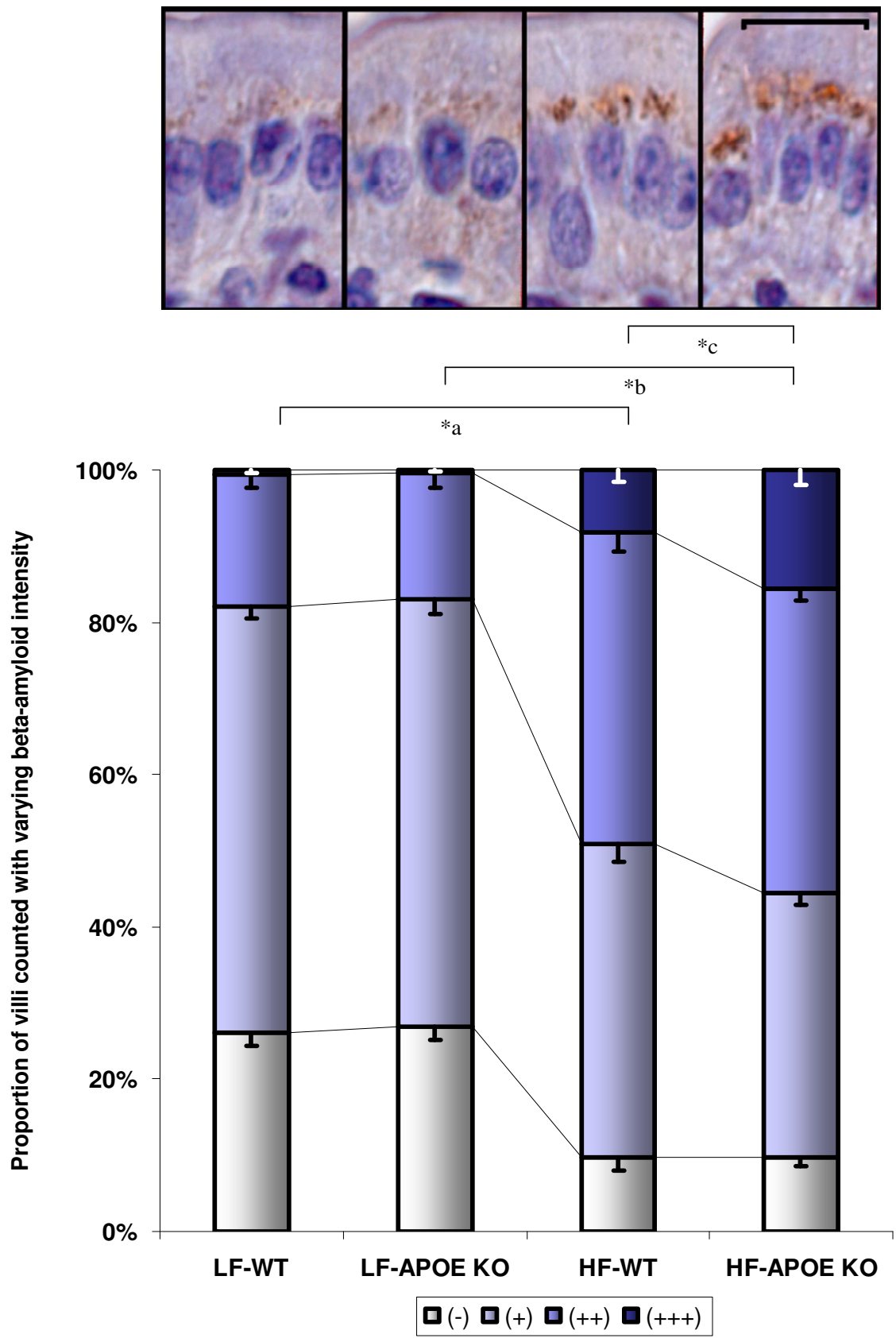

Figure I

Enterocytic $\mathbf{A} \beta$ in wild-type and apolipoprotein $\mathbf{E}$ knockout mice given a high fat diet. Figure shows proportion of small intestinal epithelial cells with different staining intensity for A $\beta$. Score as follows: (-) no granular coloration, (+) modest with I-2 granules, (2+) moderate with 3-4 granules or (3+) high, containing larger intense granules. Data was collected for six mice per group, with a minimum of four tissue sections per mouse studied. A minimum of 200 cells per section were scored and statistical significance was determined by one-way ANOVA with post-hoc Bonferroni test. LF-WT and LF-APOE KO mice have significantly $(P<0.05)$ fewer cells which stained positive for A $\beta$ compared to mice fed high fats (HF-WT and HF-APOE $\mathrm{KO} * \mathrm{a}$ and $* \mathrm{~b}$ respectively). Under high-fat feeding, apo E KO mice had significantly greater proportion of cells which expressed $A \beta$ at higher intensity compared to high-fat fed WT mice (*c, $p<0.05)$. The inset micrograph shows high-magnification of enterocytes from groups corresponding to graphs below. Beta-amyloid colocalized within the perinuclear regions of the cell containing Golgi and ER within enterocytes from all groups. (Scale bar $=20 \mu \mathrm{m}$ ). 
exhibited positive staining of $A \beta$ relatively evenly distributed throughout the mucosa epithelium. Apo E KO mice on low-fat diets showed a similar distribution of $A \beta$ compared to WT controls (figure 1). The effect of high-fat feeding on enterocytic $A \beta$ in WT and apo E KO mice is also given in figure 1 . Both WT and apo E KO mice had significantly greater enterocytic $A \beta$ abundance, however the effect was more pronounced in the apo E knockout group, notably with more enterocytes showing intense (3+) staining (double asterisks, figure 1).

Villi height in apo E KO mice and effects of high fat feeding Small intestinal villi length was determined as a surrogate marker of intestinal absorptive capacity. Apo E KO mice on the low-fat diet had significantly greater mean villi length compared to WT controls (figure 2). High-fat feeding was found to substantially increase villi length in control animals and was comparable to apo E KO mice. Highfat feeding had no synergistic influence on villi length in the absence of apo E expression (figure 2).

\section{Discussion}

This study shows that in the absence of apo E, intestinal villi length is significantly greater than WT mice. The absence of apo E coupled with chronic ingestion of a saturated fat and cholesterol diet, increased enterocytic $A \beta$ abundance compared to WT mice on a low-fat diet. This may have simply been a dietary-fat induced effect independent of apo E, because apo E KO mice on a low-fat diet showed similar levels of enterocytic A $\beta$ compared to WT controls. On the other hand, the absence of apo E with a high-fat diet was found to enhance $A \beta$ abundance above that observed in WT mice given saturates and cholesterol. The latter is consistent with modulation of $\mathrm{A} \beta$ by apo $\mathrm{E}$ that is lipid-threshold dependent.

Apolipoprotein E serves as a TRL ligand for both the LDL receptor and LRP [24,25]. The liver is a major source of apo $\mathrm{E}$, however other tissues including the small intestine express apo E [24,26,27]. Apo E KO mice [28-30] accumulate TRL's because they are unable to bind and be cleared by receptor processes [31]. Under low-fat feeding, apo E KO mice had a greater than three-fold increase in plasma. High-fat feeding exacerbated plasma cholesterol accumulation in apo E KO mice, presumably because of exaggerated lipoprotein production and indeed hypercholesterolemia was increased two-fold above lowfat fed apo E KO mice. Clearance of TRL's from blood is a two-step process requiring triglyceride lipolysis by lipases to produce a depleted apo E rich 'remnant' lipoprotein [24]. Thereafter, remnants are cleared by receptor pathways utilizing apo $\mathrm{E}$ as the ligand. There is no hydrolytic defect in apo E KO mice, which explains why these mice were not hypertriglyceridemic.
The mechanisms by which the absence of apo E increased enterocytic $A \beta$ in high-fat fed mice are unclear, although studies in cell culture provide clues. Irizarry et al (2004) found that incubation of neuronal cells with apo $\mathrm{E}$ resulted in a reduced synthesis of $A \beta$ by lowering the gamma secretase activity [4]. Rough endoplasmic reticulum (rER) and the Golgi compartments are where early endoplasmic cleavage of the A $\beta$ precursor protein occurs, the latter consistent with increased enterocytic perinuclear $\mathrm{A} \beta$ immunostaining in apo $\mathrm{E} \mathrm{KO}$ mice.

This study and others [32,33] found longer villi length in apo E KO mice, suggestive of greater absorptive capacity. Greater substrate availability might stimulate $A \beta$ biogenesis and this hypothesis is supported by the increase in $A \beta$ abundance in high-fat WT mice which also had a marked increase in villus length. Greater $A \beta$ abundance would have been expected in apo $\mathrm{E} \mathrm{KO}$ mice given the low-fat diet compared to WT controls, because villus length was comparatively greater in the absence of the apo E gene. However, if lipid absorption is already efficient with the low-fat feeding regimen; the deletion of apo $\mathrm{E}$ (and increased villus length) would not necessarily have had the expected stimulatory effect on enterocytic $A \beta$.

Chylomicron synthesis occurs within the ER and Golgi requiring the progressive lipidation of apolipoprotein $B_{48}$ $\left(\right.$ apo $B_{48}$ ) [34,35]. Dietary fats transiently stimulate chylomicron synthesis and secretion [36,37] and in clinical studies post-prandial elevations in the $A \beta$-precursor protein have been reported synergistic with the lipaemic response [3]. How A $\beta$ binds and is secreted with chylomicron is unclear, although the protein is known to bind avidly with negatively charged hydrophobic lipids $[5,38]$. Cell culture studies also support a lipoprotein mediated secretory pathway because in hepatocyte media, $A \beta$ is found associated with lipoprotein complexes [11].

In animal models and in cell cultures, apo E has confounding effects on hepatic secretion of VLDL. Apo E will normally suppress apo B production, but this is contradicted in the presence of lipids which strongly stimulate lipoprotein biogenesis [39]. In this study, enterocytic $A \beta$ abundance was not significantly different in low-fat apo $\mathrm{E}$ KO mice compared to controls, suggesting that chylomicron synthetic rates were not different between these two groups of mice. The increased availability of dietary lipids when animals were fed the high-fat diet would promote chylomicron production and by extension, perhaps $A \beta$ genesis. However, whilst enhanced enterocytic abundance of $\mathrm{A} \beta$ was seen in both WT and apo E KO mice given the high-fat diet, the effect was greater in the latter. One explanation is the finding that apo E normally suppresses triglyceride secretion from liver. Therefore, the enhanced effect on enterocytic $A \beta$ seen in apo $E$ KO given high-fat 


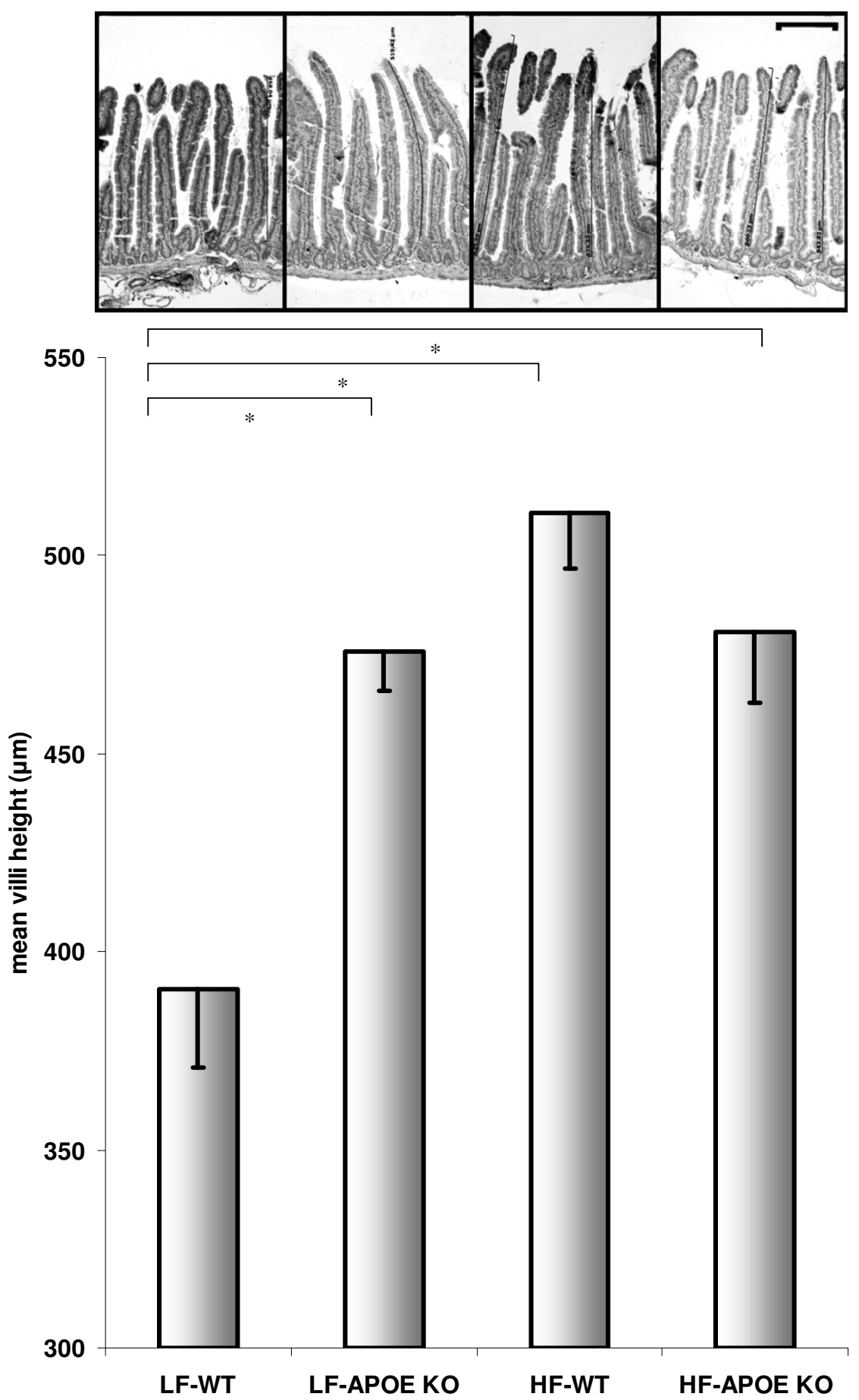

Figure 2

Villi height in wild-type and apolipoprotein E knockout mice given a high fat diet. Mean villi height (mm) in WT and apo E KO mice fed low- and high-fat chow. LF-WT group had significantly $\left({ }^{*} p<0.05\right)$ shorter villi height compared to other groups. The inset micrograph shows low-magnification of intestinal villi height for each group. (Scale bar $=200 \mu \mathrm{m}$ ). 
may have been indicative of amplification in the presence of greater cytosolic lipids $[39,40]$.

\section{Conclusion}

Many studies have demonstrated the central role of apo $\mathrm{E}$ in maintaining cerebral $A \beta$ homeostasis including modulation of production, as a chaperone protein, and in maintaining efflux and influx pathways across the blood brain barrier. Furthermore, apo E profoundly influences the kinetics in blood of $A \beta$ containing lipoproteins as well as their secretion from liver. This study now demonstrates that apo E may also regulate intestinal $\mathrm{A} \beta$ metabolism.

\section{Materials and methods \\ Animals}

The protocols described were approved by an ethics committee accredited by the National Health and Medical Research Council of Australia (Curtin University ethics approval N 55-04). Six-week-old female C57BL/6J apolipoprotein E gene knockout (apo E KO) and wild-type (WT) mice weighing approximately $16 \mathrm{~g}$ were obtained from the Animal ARC, Perth, Western Australia. Mice were divided and randomly allocated into a low-fat or high-fat diet group. Mice were housed separately in a well-ventilated room that was maintained at $22^{\circ} \mathrm{C}$ on a $12: 12$-h light/dark cycles. Body weight was measured weekly.

\section{Dietary regimen}

Chow was purchased from Rodent Diet Specialty Feeds (Glen Forrest, Western Australia). The low-fat (control) group of mice was given chow that contained $4.0 \%(\mathrm{w} / \mathrm{w})$ as unsaturated fat (AIN93M standard rodent diet) and the diet was free of cholesterol. Mice on the high-fat diet were given chow containing $1.0 \%(\mathrm{w} / \mathrm{w})$ as unsaturated fat and $16.0 \%(\mathrm{w} / \mathrm{w})$ as saturated fat (SF00-245 high-fat mouse diet). In addition, the high-fat feed was supplemented with $1 \%(\mathrm{w} / \mathrm{w})$ cholesterol and $0.5 \%(\mathrm{w} / \mathrm{w})$ cholate, the latter to aid in absorption. The digestible energy for lowfat and high-fat feed were $15.2 \mathrm{MJ} / \mathrm{kg}$ and $18.7 \mathrm{MJ} / \mathrm{kg}$ respectively. Food and water were available ad libitum.

\section{Sample collection}

After six-months of dietary interventions, mice were anaesthetized with an intraperitoneal injection of Phenobarbital $(45 \mathrm{mg} / \mathrm{kg})$. Mice were exsanguinated by cardiac punctureand blood was collected into ethylene-diaminetetracetic acid (EDTA)-tubes. Plasma was separated by low speed centrifugation and stored at $-80^{\circ} \mathrm{C}$ (under an atmosphere of argon).

\section{Tissue processing}

A small intestine segment measuring $2 \mathrm{~cm}$ was cut and isolated from the rest of the digestive tract at the proximal duodenal sphincter. The contents were flushed in-situ with phosphate buffered saline (PBS, $\mathrm{pH}=7.4$ ), and placed into $10 \%$ buffered formalin ( $\mathrm{ph}=7.4$ ) for fixation. Tissues were fixed for $24 \mathrm{~h}$ and processed for immunohistochemistry (IHC).

\section{Immunohistochemistry}

Tissue sections $(5 \mu \mathrm{m})$ were deparaffinised, rehydrated and IHC analysis was done as previously described [21]. Briefly, the sections were exposed to 3\% hydrogen peroxide in methanol for 30 min to quench endogenous peroxidase activity, washed and incubated in blocking serum $\left(20 \%\right.$ goat serum) prior to overnight incubation at $4{ }^{\circ} \mathrm{C}$ with polyclonal rabbit anti-human $A \beta_{1-40 / 42}$ antiserum (AB5076, Chemicon Temecula, CA), diluted to 1:1000 with $10 \%$ goat serum. We previously established specificity by replacing the primary antibody with an irrelevant serum or with PBS and by competition IHC analysis [21]. For the latter, the primary antisera were pre-mixed with solubilised $A \beta$. Cerebral tissues from transgenic mice (Tg2576sw) expressing familial human APP695 with established plaques were used as positive controls. Slides were washed in PBS and incubated with biotinylated goat anti-rabbit secondary antibody (1:1000 dilution) (E 0432, DAKO, Carpinteria, CA), followed by avidinbiotin-peroxidase complex (ABC/HRP) (K 0377, DAKO, Carpinteria, CA) for $45 \mathrm{~min}$ at room temperature. Positive immunostaining was established with liquid diaminobenzidine plus $(\mathrm{DAB}+)$ substrate chromogen kit $(\mathrm{K}$ 3467, DAKO, Carpinteria, CA). Sections were then counterstained with Harris's haematoxylin.

\section{Imaging}

Digital images for photomicroscopy were acquired by AxioCam HRc camera (Zeiss Germany). Images were captured under identical settings utilising AxioVision software, version 4.5.

\section{Quantitation of intestinal beta-amyloid abundance}

Six animals per group were investigated with a minimum of four tissue blocks prepared for each. From each slide, four images were captured randomly at low magnification (Zeiss AxioVert 200 M, Germany). The intensity of immunolabeling was quantified as previously described $[41,42]$. Labelling was considered adequate if it was mild $(+)$, moderate $(2+)$, or intense $(3+)$, with adequately labeled positive controls and no labeling in negative controls. The total number of cells with different intensity of $\mathrm{A} \beta$ staining was counted by a blinded-to-group investigator in each villus and the data expressed as a percentage.

\section{Measurements of intestinal villi height}

Total of 8 images was taken at low-magnification per group. Representative villi were selected by two independent investigators for height measurement (measurement tool, AxioVision program 4.5). 


\section{Plasma lipid measurements}

Plasma lipids were measured immediately following plasma isolation via commercial absorbance-based assays. Triglyceride was determined by measurement of glycerol liberated following enzymatic hydrolysis of triglyceride (TR 1697, Randox laboratories, U.K). Total plasma cholesterol concentration was determined via the cholesterol esterase/cholesterol oxidase technique $(\mathrm{CH}$ 201, Randox laboratories, U.K).

\section{Statistical analysis}

The effect of high-fat feeding and apo E gene on $\mathrm{A} \beta$ abundance, intestinal villi height, plasma triglyceride and total cholesterol was assessed by univariate analysis. Post-hoc comparisons of means were performed using Bonferroni tests and if equal variance was not found, then GamesHowell test was used to compare difference between individual groups. P-value $<0.05$ was considered a statistically significant.

\section{List of abbreviations}

A $\beta$ : beta-amyloid; AD: Alzheimer's disease; Apo: apolipoprotein; APP: amyloid precursor protein; $\mathrm{CH}$ : cholesterol; IHC: immunohistochemistry; KO: knockout; TG: triglycerides; TRL: triglyceride-rich-lipoprotein; WT: wild-type.

\section{Competing interests}

The authors declare that they have no competing interests.

\section{Authors' contributions}

SG participated in the design of the study, carried out the study, performed the IHC and lipid analysis and helped to draft the manuscript. MMSPG helped to collect data for results analysis. RT helped to collect data for results analysis. LJ participated in the design of study and performed the statistical analysis. RDJ participated in design of study and helped to draft the manuscript. SSD helped with performing statistical analysis. JCLM participated in the design of the study, performed statistical analysis, and coordinated and helped to draft the manuscript. All authors read and approved the final manuscript.

\section{Acknowledgements}

The authors would like to thank Columbur Cheung and Karl Fairhurst for technical assistance.

\section{References}

I. DeMattos RB: Apolipoprotein E dose-dependent modulation of beta-amyloid deposition in a transgenic mouse model of Alzheimer's disease. J Mol Neurosci 2004, 23:255-262.

2. Bales KR, Verina T, Cummins DJ, Du Y, Dodel RC, Saura J, Fishman CE, Delong CA, Piccardo P, Petegnief V, Ghetti B, Paul SM: Apolipoprotein $E$ is essential for amyloid deposition in the APP(V7I7F) transgenic mouse model of Alzheimer's disease. Proc Natl Acad Sci U S A 1999, 96: I5233-I5238.

3. Boyt AA, Taddei K, Hallmayer J, Mamo J, Helmerhorst E, Gandy SE, Martins RN: Relationship between lipid metabolism and amyloid precursor protein and apolipoprotein E. Alzheimer's Reports 1999, 2:339-346.
4. Irizarry MC, Deng A, Lleo A, Berezovska O, Von Arnim CA, MartinRehrmann M, Manelli A, LaDu MJ, Hyman BT, Rebeck GW: Apolipoprotein $E$ modulates gamma-secretase cleavage of the amyloid precursor protein. I Neurochem 2004, 90: I I32-I I 43.

5. James AP, Pal S, Gennat HC, Vine DF, Mamo JC: The incorporation and metabolism of amyloid-beta into chylomicron-like lipid emulsions. J Alzheimers Dis 2003, 5: I79-188.

6. LaDu MJ, Lukens JR, Reardon CA, Getz GS: Association of human, rat, and rabbit apolipoprotein $E$ with beta-amyloid. J Neurosci Res 1997, 49:9-18.

7. Strittmatter WJ, Weisgraber KH, Huang DY, Dong LM, Salvesen GS, Pericak-Vance M, Schmechel D, Saunders AM, Goldgaber D, Roses $A D$ : Binding of human apolipoprotein $E$ to synthetic amyloid beta peptide: isoform-specific effects and implications for late-onset Alzheimer disease. Proc Natl Acad Sci U S A 1993, 90:8098-8102.

8. Ye S, Huang Y, Mullendorff K, Dong L, Giedt G, Meng EC, Cohen FE, Kuntz ID, Weisgraber KH, Mahley RW: Apolipoprotein (apo) E4 enhances amyloid beta peptide production in cultured neuronal cells: apoE structure as a potential therapeutic target. Proc Natl Acad Sci U S A 2005, I 02: | 8700- 18705.

9. Deane R, Du Yan S, Submamaryan RK, LaRue B, Jovanovic S, Hogg E, Welch D, Manness L, Lin C, Yu J, Zhu H, Ghiso J. Frangione B, Stern A, Schmidt AM, Armstrong DL, Arnold B, Liliensiek B, Nawroth P, Hofman F, Kindy M, Stern D, Zlokovic B: RAGE mediates amyloid-beta peptide transport across the blood-brain barrier and accumulation in brain. Nat Med 2003, 9:907-913.

10. Dodart JC, Bales KR, Gannon KS, Greene SJ, DeMattos RB, Mathis C, DeLong CA, Wu S, Wu X, Holtzman DM, Paul SM: Immunization reverses memory deficits without reducing brain Abeta burden in Alzheimer's disease model. Nat Neurosci 2002, 5:452-457.

II. Koudinov AR, Koudinova NV: Alzheimer's soluble amyloid beta protein is secreted by HepG2 cells as an apolipoprotein. Cell Biol Int 1997, 2 I:265-27I.

12. Mahley RW: Apolipoprotein E: cholesterol transport protein with expanding role in cell biology. Science 1988, 240:622-630.

13.

14. Morris MC, Evans DA, Bienias JL, Tangney CC, Bennett DA, Aggarwal $\mathrm{N}$, Schneider J, Wilson RS: Dietary fats and the risk of incident Alzheimer disease. Arch Neurol 2003, 60:194-200.

15. Kalmijn S, Launer LJ, Ott A, Witteman JC, Hofman A, Breteler MM: Dietary fat intake and the risk of incident dementia in the Rotterdam Study. Ann Neurol 1997, 42:776-782.

16. Engelhart MJ, Geerlings MI, Ruitenberg A, Van Swieten JC, Hofman A, Witteman JC, Breteler MM: Diet and risk of dementia: Does fat matter?: The Rotterdam Study. Neurology 2002, 59:1915-1921.

17. Luchsinger JA, Mayeux R: Dietary factors and Alzheimer's disease. Lancet Neurol 2004, 3:579-587.

18. Solfrizzi V, D'Introno A, Colacicco AM, Capurso C, Del Parigi A, Capurso S, Gadaleta A, Capurso A, Panza F: Dietary fatty acids intake: possible role in cognitive decline and dementia. Exp Gerontol 2005, 40:257-270.

19. Sparks DL, Scheff SW, Hunsaker JC 3rd, Liu H, Landers T, Gross DR: Induction of Alzheimer-like beta-amyloid immunoreactivity in the brains of rabbits with dietary cholesterol. Exp Neurol 1994, I 26:88-94.

20. Refolo LM, Malester B, LaFrancois J, Bryant-Thomas T, Wang R, Tint GS, Sambamurti K, Duff K, Pappolla MA: Hypercholesterolemia accelerates the Alzheimer's amyloid pathology in a transgenic mouse model. Neurobiol Dis 2000, 7:32I-33I.

21. Shie FS, Jin LW, Cook DG, Leverenz JB, LeBoeuf RC: Diet-induced hypercholesterolemia enhances brain $A$ beta accumulation in transgenic mice. Neuroreport 2002, 13:455-459.

22. Galloway S, Le J, Johnsen R, Chew S, Mamo JCL: Beta-amyloid or its precursor protein is found in epithelial cells of the small intestine and stimulated by high fat feeding. Journal of Nutritional Biochemistry 2006, In press:.

23. Su GC, Arendash GW, Kalaria RN, Bjugstad KB, Mullan M: Intravascular infusions of soluble beta-amyloid compromise the blood-brain barrier, activate CNS glial cells and induce peripheral hemorrhage. Brain Res 1999, 81 8: I05-I I7.

24. Mahley RW, Hui DY, Innerarity TL, Weisgraber KH: Two independent lipoprotein receptors on hepatic membranes of dog, swine, and man. Apo-B,E and apo-E receptors. J Clin Invest 1981, 68: I 197-1206. 
25. Hui DY, Innerarity TL, Mahley RW: Lipoprotein binding to canine hepatic membranes. Metabolically distinct apo-E and apoB,E receptors. J Biol Chem I 98I, 256:5646-5655.

26. Driscoll DM, Getz GS: Extrahepatic synthesis of apolipoprotein E. J Lipid Res 1984, 25:1368-1379.

27. Emanuele E, Peros E, Tomaino C, Feudatari E, Bernardi L, Binetti G, Maletta R, D'Angelo A, Montagna L, Bruni AC, Geroldi D: Apolipoprotein(a) null phenotype is related to a delayed age at onset of Alzheimer's disease. Neurosci Lett 2004, 357:45-48.

28. Zhang SH, Reddick RL, Piedrahita JA, Maeda N: Spontaneous hypercholesterolemia and arterial lesions in mice lacking apolipoprotein E. Science 1992, 258:468-47I.

29. Plump AS, Smith JD, Hayek T, Aalto-Setala K, Walsh A, Verstuyft JG, Rubin EM, Breslow JL: Severe hypercholesterolemia and atherosclerosis in apolipoprotein E-deficient mice created by homologous recombination in ES cells. Cell 1992, 7l:343-353.

30. Nakashima Y, Plump AS, Raines EW, Breslow JL, Ross R: ApoE-deficient mice develop lesions of all phases of atherosclerosis throughout the arterial tree. Arterioscler Thromb 1994 I 4: I33-140.

31. Hultin M, Olivecrona T: Conversion of chylomicrons into remnants. Atherosclerosis 1998, I4I(Suppl I):25-29.

32. Kanemitsu N, Shimamoto C, Hiraike Y, Omae T, Iwakura K, Nakanishi $Y$, Katsu K: Fat Absorption and Morphological Changes in the Small Intestine in Model Mice with Hyperlipidemia (Apo E Deficiency). Bulletin of the Osaka Medical College 2006, 52:59-67.

33. Kesaniemi YA, Ehnholm C, Miettinen TA: Intestinal cholesterol absorption efficiency in man is related to apoprotein $E$ phenotype. J Clin Invest 1987, 80:578-58I.

34. Hussain MM, Kedees MH, Singh K, Athar H, Jamali NZ: Signposts in the assembly of chylomicrons. Front Biosci 200I, 6:D320-31.

35. van Greevenbroek MM, van Meer G, Erkelens DW, de Bruin TW: Effects of saturated, mono-, and polyunsaturated fatty acids on the secretion of apo B containing lipoproteins by Caco-2 cells. Atherosclerosis 1996, I 2 I: I39-150.

36. van Greevenbroek MM, de Bruin TW: Chylomicron synthesis by intestinal cells in vitro and in vivo. Atherosclerosis 1998, I4 | Suppl I:S9-16.

37. Luchoomun J, Hussain MM: Assembly and secretion of chylomicrons by differentiated Caco-2 cells. Nascent triglycerides and preformed phospholipids are preferentially used for lipoprotein assembly. J Biol Chem 1999, 274: 19565-19572.

38. Shao H, Jao SC, Ma K, Zagoriski MG: Solution Structures of Michelle-bound Amyloid betal-40 and betl-42 Peptides of Alzheimer's Disease. J Mol Biol 1999, 285:755-773.

39. Maugeais C, Tietge UJ, Tsukamoto K, Glick JM, Rader DJ: Hepatic apolipoprotein E expression promotes very low density lipoprotein-apolipoprotein B production in vivo in mice. J Lipid Res 2000, 4I:1673-1679.

40. Mensenkamp AR, Van Luyn MJ, Havinga R, Teusink B, Waterman IJ, Mann CJ, Elzinga BM, Verkade HJ, Zammit VA, Havekes LM, Shoulders CC, Kuipers F: The transport of triglycerides through the secretory pathway of hepatocytes is impaired in apolipoprotein E deficient mice. J Hepatol 2004, 40:599-606.

41. Mikaelian I, Nanney LB, Parman KS, Kusewitt DF, Ward JM, Naf D, Krupke DM, Eppig JT, Bult CJ, Seymour R, Ichiki T, Sundberg JP: Antibodies that label paraffin-embedded mouse tissues: a collaborative endeavor. Toxicol Pathol 2004, 32: |8|-|9|

42. Donahue JE, Flaherty SL, Johanson CE, Duncan JA 3rd, Silverberg GD, Miller MC, Tavares R, Yang W, Wu Q, Sabo E, Hovanesian V, Stopa EG: RAGE, LRP-I, and amyloid-beta protein in Alzheimer's disease. Acta Neuropathol 2006, I I 2:405-4I 5.

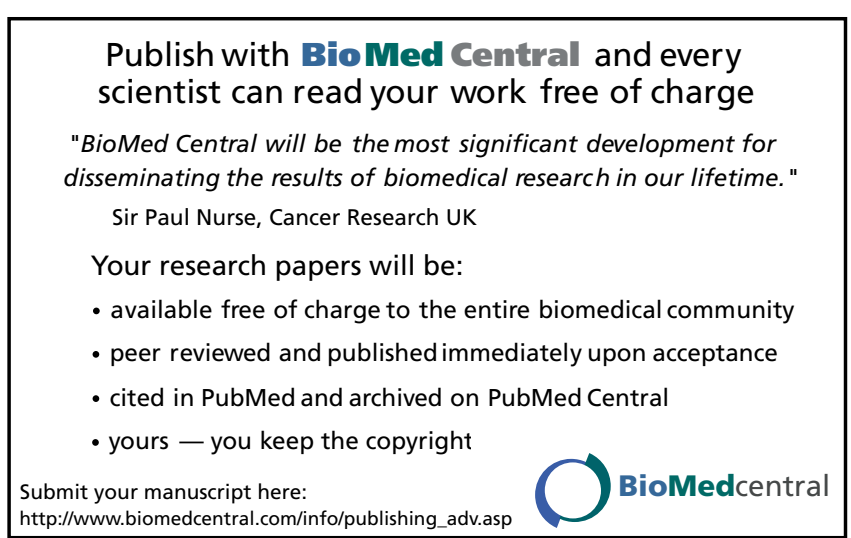

